\title{
Correction to: Critical LPP and the intersection of class, race and language policy and practice in twenty first century
}

\section{Catalonia}

\section{David Block $^{1}$ (D) Victor Corona ${ }^{2}$}

Published online: 16 July 2020

(c) Springer Nature B.V. 2020

\section{Correction to: Language Policy https://doi.org/10.1007/s10993-018-09508-7}

In the original article the affiliation and the e-mail address for author David Block were incorrectly published. These have been corrected with this Correction.

Publisher's Note Springer Nature remains neutral with regard to jurisdictional claims in published maps and institutional affiliations.

The original article can be found online at https://doi.org/10.1007/s10993-018-09508-7.

\section{David Block}

davidmartin.block@upf.edu

Victor Corona

victor.corona@dal.udl.cat

1 ICREA, Grup de Recerca en Espais Interculturals, Llengües i Identitats (GREILI), Departament d'Humanitats, Universitat Pompeu Fabra, Trias Fargas 25-27, 08005 Barcelona, Spain

2 Departament d'Anglès i Lingüística, Universitat de Lleida, Plaça de Víctor Siurana 1, 25003 Lleida, Catalonia, Spain 